\title{
WINTERTIME WET AND DRY DEPOSITION IN NORTHERN MICHIGAN
}

\author{
Steven H. Cadle and Jean Mulbaier Dasch \\ Environmental Science Department, General Motors Research Laboratories, Warren, MI 48090, U.S.A.
}

and

RoBert V ANDE KopPLE

University of Michigan Biological Station, Pellston, MI 49769, U.S.A.

(First received 17 April 1985 and in final form 28 October 1985)

\begin{abstract}
Wet and dry deposition were monitored at the University of Michigan Biological Station in rural northern Michigan for three winters. Dry deposition was measured by both the conventional bucket method and by measuring increases in concentration in exposed, elevated snow samples. Average results of the two methods were in reasonable agreement. The cumulative wet and dry deposition quantities are in good agreement with snowpack accumulations until the first thaw period. Dry deposition to snow accounts for less than $15 \%$ of the total $\mathrm{H}^{+}, \mathrm{SO}_{4}^{2-}, \mathrm{NO}_{3}^{-}$, and $\mathrm{NH}_{4}^{+}$and approximately $25 \%$ of the $\mathrm{Ca}^{2+}, \mathrm{Mg}^{2+}, \mathrm{Na}^{+}, \mathrm{K}^{+}$and $\mathrm{Cl}^{-}$during an average precipitation year. Snowpack measurements were also made under deciduous and red pine canopies. Decreases in $\mathrm{H}^{+}$and $\mathrm{NO}_{3}^{-}$were observed under the red pine canopy.
\end{abstract}

Key word index: Dry deposition, snow, snowpack, throughfall.

\section{INTRODUCTION}

Snow covers a large portion of $\mathrm{N}$ America for several months of the year. The acidity of the snowpack is of concern because its release during the spring melt can cause acid shock. While a large body of information is available on the acid content of both wet deposition and the snowpack, little information exists on the amount of dry deposition to snow. Three approaches have been used to estimate dry deposition rates to snow: bucket collection, deposition velocity calculations, and direct measurements. Wet/dry bucket collection techniques are in use by several acid deposition monitoring networks. However, little use has been made of the dry deposition data because of the uncertainty involved in relating surrogate surface collection to actual dry deposition rates. While some researchers consider bucket measurements to be useful for some species (Johannes et al, 1982), others feel that their problems are insurmountable (Hicks et al., 1980). More information comparing bucket measurements of various species to actual dry deposition rates to different surfaces is needed.

The use of deposition velocities to calculate dry deposition rates to snow has been hampered by a lack of continuous atmospheric concentration data in rural areas and by large uncertainties in deposition velocities. A recent study of $\mathbf{S}$ deposition in rural Canada (Barrie et al., 1984) concluded that wet and dry deposited $\mathbf{S}$ were similar during the winter. However, the dry deposition may have been overestimated since the $\mathrm{SO}_{2}$ deposition velocity used in these calculations $\left(0.15-0.18 \mathrm{~cm} \mathrm{~s}^{-1}\right)$ is higher than the $<0.10 \mathrm{~cm} \mathrm{~s}^{-1}$ deposition velocity reported elsewhere (Grant and Johansson, 1983; Cadle et al., 1985).

Several studies have measured dry deposition rates to snow by determining the increase in concentration of the dry deposited species in snow after exposure to the atmosphere. Most studies have been of short duration. For example, Forland and Gjessing (1975) collected snow from 46 locations in Norway just after a snowfall and then 3 days later. They found that wet and dry deposition were roughly equal in urban areas. but that the wet deposition dominates in rural areas. More recently Reynolds (1983) studied the snowpack in Wales and observed concentration increases in the surface snow. In contrast to previous studies, it was concluded that old snow is essentially the same as fresh snow and that concentration changes are due to freeze-thaw mechanisms.

This paper presents results of a study of wet and dry deposition during three winters at a site in N Michigan. Dry deposition was measured with both a bucket collector and by measuring concentration increases in snow samples. The sum of the wet and dry deposition is compared to the snowpack loading. Deposition velocities calculated with this dry deposition rate data are reported elscwhere (Cadle et al., 1985).

\section{EXPERIMENTAL}

\subsection{Sampling}

Sampling was conducted in a 25 -m diameter circular, open field surrounded by deciduous forest at the University of Michigan Biological Station. This feld is also a National Acid Deposition Program (NADP) site. The station is located near 
the tip of Michigan's lower peninsula, approximately $350 \mathrm{~km}$ $\mathrm{N}$ of Detroit. Samples were collected during the 1982-1983 and 1983-1984 winters. Results from a 1981-1982 winter study conducted at the same site are included for comparison. These results have been discussed in detail elsewhere (Cadle $\mathrm{et}$ al., 1984).

Wet deposition samples were collected weekly with a Wong wet only sampler during the 1982-1983 winter and with an Aerochem Metrics sampler during the 1983-1984 winter. Dry deposition was also collected weekly using both a standard polyethylene bucket and a modified bucket filled with snow mounted in conventional wet/dry samplers. In the 1982-1983 winter the dry deposition collectors were in separate Wong samplers. In the 1983-1984 winter they were in Aerochem Metrics samplers. The standard dry deposition sample was extracted by placing $250 \mathrm{ml}$ of distilled water into the bucket and allowing it to sit overnight. The water was swirled approximately halfway up the bucket wall. The dry de. position area was taken as the open area of the bucket mouth, $635 \mathrm{~cm}^{2}$. This area ignores possible wall effects. Dasch (1984) showed that $7-28 \%$ of the total material collected by a bucket was present on the walls. Since only half of the wall was washed in these experiments, the wall contribution could have been lower. On the other hand, site and seasonal variations in wall contributions are not known. The modified bucket was a conventional bucket cut down to a depth of $2.0 \mathrm{~cm}$ to reduce its volume. The bucket area was $530 \mathrm{~cm}^{2}$. Four modified buckets were filled with snow each week. Three of the samples were retained as blanks while the fourth was mounted in the dry-only sampler. The sampler was modified so that the rim of the cut-off bucket was located at the same height as the rim of a standard sample bucket. Errors involved in this type of sampling are discussed elsewhere (Cadle et al., 1985).

It is not uncommon for some snow to be collected by the dry side of a wet/dry collector. This problem occurs most frequently with light snows which fail to activate the wet/dry sensor. When snow was collected in the dry deposition bucket or the modified snow filled bucket, its volume was determined and included in the total wet deposition volume. Wet deposition concentrations were not changed, i.e. it was assumed that the snow collected in the dry bucket had the same concentration as the wet deposition. The dry deposition rate was adjusted to account for wet deposition input into the bucket. Twenty two of the 28 dry deposition bucket samples collected during the 1982-1983 and 1983-1984 periods collected some wet deposition. Twelve out of 26 of the modified snow filled buckets had measurable increases in volume; all reported dry deposition values have been corrected for the wet deposition input. The average volume collected in the dry bucket, $124 \mathrm{ml}$, was $11 \%$ of the total wet deposition.

The total precipitation determined with the buckets was compared to the total precipitation determined from daily readings of a Belfort gaugc. Cumulative bucket measurements were $2 \%$ higher in 1982-1983 and $6 \%$ higher in 1983-1984 than the cumulative Belfort gauge readings.

Triplicate snow cores were collected weekly in the open field using $10.2 \mathrm{~cm}$ i.d. plexiglass tubes. Cores were transferred to beakers and allowed to melt at room temperature. During the 1982-1983 winter, cores were also collected in triplicate under the deciduous canopy immediately adjacent to the open field and under a red pine canopy located nearby.

\subsection{Analysis}

All samples were filtered through $0.4-\mu \mathrm{m}$ pore size Nuclepore filters shortly after collection and refrigerated until analysis. $\mathrm{SO}_{4}^{2-}, \mathrm{NO}_{3}^{-}$and $\mathrm{Cl}^{-}$were determined with a Dionex Model $2110 \mathrm{i}$ ion chromatograph. $\mathrm{Ca}^{2+}$ and $\mathrm{Mg}^{2+}$ were determined with a Perkin-Elmer 403 atomic absorption spectrometer after addition of $\mathrm{La}_{2} \mathrm{O}_{3} . \mathrm{Na}^{+}$and $\mathrm{K}^{+}$were determined on the same spectrometer after addition of $\mathrm{LiCl}$. $\mathrm{NH}_{*}^{+}$was determined with a Lachat Quick Chem flow injection analyzer.

\section{RESULTS AND DISCUSSION}

\subsection{Climate}

The Biological Station is located $9 \mathrm{~km} \mathrm{E}$ of the Pellston weather station. The 1942-1969 climatological data from the Pellston Station (Michigan Department of Agriculture, 1971) show that the average annual snowfall is $2.49 \mathrm{~m}$ and that the average number of days with one or more inches of snow on the ground is 126. Total precipitation during the December-March period is $25 \%$ of the annual average precipitation.

The data presented in this report is for the period during which there was a continuous snowpack. The three winters were quite different. During the 1981-1982 winter there were 18.5 weeks of continuous snowpack with a maximum depth of $0.77 \mathrm{~m}$ (Table 1). The first 13 weeks were the stable snowpack periodthat period in which there were no thaws. The succeeding 5.5 weeks saw a slow, continuing thaw. The 1982-1983 winter was unusually mild with a total snowpack period of 10 weeks and a maximum snow depth of $0.38 \mathrm{~m}$. The stable snowpack period was 7 weeks. The 1983-1984 snowpack period was 18 weeks with a heavier than normal snowfall of $3.1 \mathrm{~m}$. A thaw in early February ended the stable snowpack period at 10 weeks, but was followed by several weeks of cold weather.

Soil freezing was monitored on a weekly basis beneath the snowpack by freeze tubes and by direct observation after coring. The soil did not freeze during the 1983-1984 study unil the end of February. It remained frozen or partially frozen through March. During the 1982-1983 study, the soil was frozen much of December, but thawed by 29 December when the snowpack started to form. It remained thawed through the rest of the study.

\subsection{Wet deposition}

The volume weighted average wet deposition concentrations are given in Table 2 for the three study periods. The deposition is clearly acidic with concentrations of major species similar to those found in the NE United States. The cation/anion ratios for the 1983-1984, 1982-1983 and 1981-1982 volume weighted average wet deposition were 1.13,1.04 and 1.11, respectively. The cause of the small positive bias in the

Table 1. Snowpack data for the three study periods

\begin{tabular}{|c|c|c|c|}
\hline & $1983-1984$ & $1982-1983$ & $1981-1982$ \\
\hline $\begin{array}{l}\text { Snowpack duration } \\
\text { (weeks) }\end{array}$ & 18 & 10 & 18.5 \\
\hline $\begin{array}{l}\text { Stable snowpacks } \\
\text { period (weeks) }\end{array}$ & 10 & 7 & 13 \\
\hline Snowfall $(m)$ & 3.12 & 0.90 & 2.36 \\
\hline $\begin{array}{l}\text { Maximum snowpack } \\
\text { depth (m) }\end{array}$ & 0.74 & 0.38 & 0.77 \\
\hline $\begin{array}{l}\text { Maximum snowpack } \\
\text { volume }\left(\mathrm{cm} \mathrm{H}_{2} \mathrm{O}\right)\end{array}$ & 16.9 & 7.9 & 16.2 \\
\hline
\end{tabular}


Table 2. Volume-weighted wet deposition concentrations

\begin{tabular}{lccc}
\hline Species & $1983-1984$ & $\begin{array}{c}1982-1983 \\
\left(\mu \mathrm{eq} 1^{-1}\right)\end{array}$ & $1981-1982$ \\
\hline $\mathrm{H}^{+}$ & 53.9 & 43.0 & 42.1 \\
& $(\mathrm{pH}=4.27)$ & $(\mathrm{pH}=4.37)$ & $(\mathrm{pH}=4.38)$ \\
$\mathrm{NO}_{3}^{-}$ & 39.7 & 28.5 & 39.7 \\
$\mathrm{SO}_{4}^{2-}$ & 35.5 & 33.0 & 43.7 \\
$\mathrm{Cl}^{-}$ & 5.1 & 2.9 & 7.1 \\
$\mathrm{NH}_{2}^{+}$ & 15.4 & 10.4 & 19.7 \\
$\mathrm{Ca}^{2+}$ & 13.2 & 7.9 & 24.2 \\
$\mathrm{Mg}^{2+}$ & 3.1 & 2.1 & 7.9 \\
$\mathrm{Na}^{+}$ & 3.7 & 2.1 & 5.1 \\
$\mathrm{~K}^{+}$ & 1.5 & 1.6 & 1.6 \\
\hline
\end{tabular}

ratio was not identified, but is most likely due to small errors in the $\mathrm{pH}$ measurements. When the acidity is proportioned to the relative equivalents of $\mathrm{SO}_{4}^{2-}$, $\mathrm{NO}_{3}^{-}$and $\mathrm{Cl}^{-}$, the three winter average \% contributions of $\mathrm{H}_{2} \mathrm{SO}_{4}, \mathrm{HNO}_{3}$, and $\mathrm{HCl}$ are 48,46 and $6 \%$, respectively.

The $\mathrm{SO}_{4}^{2-} / \mathrm{NO}_{3}^{-}$ratios for the weekly wet deposition samples are shown in Fig. 1. The $\mathrm{SO}_{4}^{2-} / \mathrm{NO}_{3}^{-}$ ratio decreases to approximately 0.5 in the middle of winter and then increases to values as high as 3.0 in the spring, A similar pattern was seen for the 1981-1982 winter (Cadle et al., 1984) and has been reported elsewhere (Galloway and Likens, 1981). Variations in the ratio are caused primarily by seasonal variations in the $\mathrm{SO}_{4}^{2-}$ concentration rather than changes in the $\mathrm{NO}_{3}^{-}$concentration. For example, the volume weighted average $\mathrm{SO}_{4}^{2-}$ and $\mathrm{NO}_{3}^{-}$concentrations during the 1983-1984 winter were 22.7 and $37.3 \mu \mathrm{eq} \ell^{-1}$, respectively, during the first 10 weeks, and 56.4 and $42.4 \mu \mathrm{eq} r^{-1}$, respectively, during the last 8 weeks. Thus, $\mathrm{HNO}_{3}$ is the dominant acid in wet deposition during early and mid winter, while $\mathrm{H}_{2} \mathrm{SO}_{4}$ is the dominant acid in the wet deposition during the late snowpack period. The late period typically includes rain. The cause of the seasonal $\mathrm{SO}_{4}^{2-}$ variation is not well established, but can probably be attributed to both decreased photochemical activity in the winter and the decrease in cloud and precipitation liquid water. The latter is an important medium for $\mathrm{SO}_{2}$ oxidation to $\mathrm{H}_{2} \mathrm{SO}_{4}$. Overall, the $\mathrm{SO}_{4}^{2-}$ and $\mathrm{NO}_{3}^{-}$wet deposition inputs during the snowpack period are similar. The $\mathrm{SO}_{4}^{2-} / \mathrm{NO}_{3}^{-}$ratios for the three winters shown in Table 2 were 0.89 (1983-1984), 1.16, (1982-1983), and 1.10 (1981-1982).

\subsection{Dry deposition}

Average dry deposition rates measured by both the conventional bucket method and the modified method, referred to as dry to snow, are given in Table 3 for the 1983-1984 and 1982-1983 winters. Also given are dry bucket data from the 1981-1982 study as well as 4 years of NADP bucket data collected at the same site. NADP dry deposition buckets are exposed for a 2 month period rather than for the weekly period used in this study. Therefore, it was not possible to precisely match the NADP sampling period to the snowpack period. The NADP dry deposition rates in Table 3 are for the 4-month period most closely matching the snowpack period. The NADP sample periods were $30 / 11 / / 82$ to $22 / / 3 / 83,29 / 12 / 81$ to $20 / 4 / 82,2 / 12 / 80$ to $24 / 3 / 81$, and $4 / 12 / 79$ to $1 / 4 / 80$. Another difference in the data sets is that the NADP data were not corrected for wet deposition inputs. Dry bucket water volumes at the time of collection for these samples were 743,1997 , 286 and $97 \mathrm{ml}$ for the 1982-1983, 1981-1982, 1980-1981 and 1979-1980 data, respectively.

The dry deposition to snow and the bucket measurements give comparable average dry deposition rates. One might expect that the dry to snow data would show higher deposition rates than the bucket data for $\mathrm{SO}_{4}^{2-}$ and $\mathrm{NO}_{3}^{-}$because it has been shown that snow collects $\mathrm{SO}_{2}$ and $\mathrm{HNO}_{3}$ (Cadle et al., 1985), while a dry bucket at room temperature does not collect these species (Dasch, 1984). A similar effect might be ex-

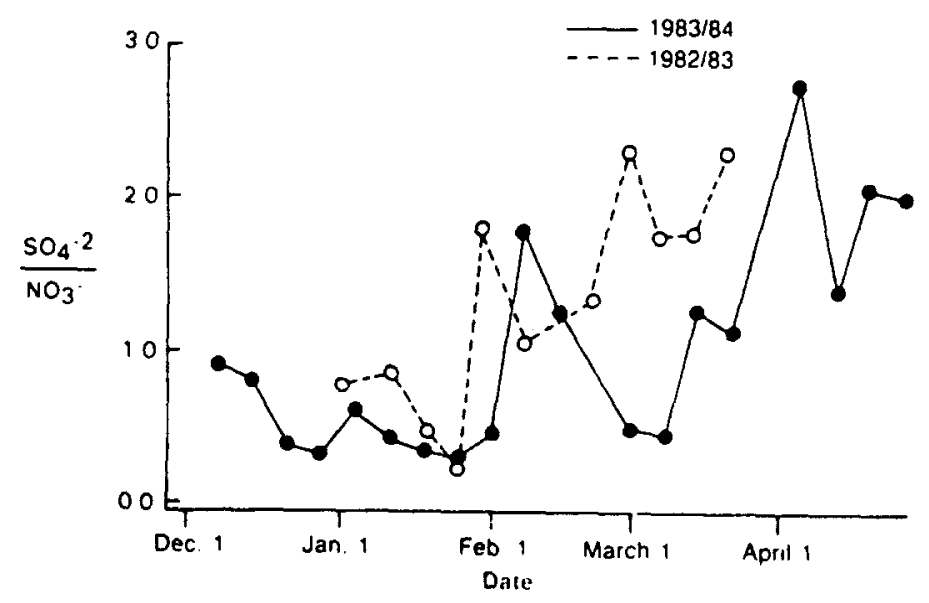

Fig. 1. $\mathrm{SO}_{4}^{2-}$ to $\mathrm{NO}_{3}^{-}$equivalents ratios in weekly wet deposition during the snowpack period. 
Table 3. Comparison of average dry deposition rates

\begin{tabular}{lcccccccc}
\hline Sample & $\mathrm{SO}_{4}^{2-}$ & $\mathrm{NO}_{3}^{-}$ & $\mathrm{Cl}^{-}$ & $\begin{array}{c}\mathrm{NH}_{4}^{+} \\
\mu \mathrm{eq} \mathrm{m} \mathbf{m}^{-2}-\mathrm{wk}\end{array}$ & $\mathrm{Ca}^{2+}$ & $\mathrm{Mg}^{2+}$ & $\mathrm{Na}^{+}$ & $\mathrm{K}^{+}$ \\
\hline Dry to snow, 1983-1984 & 60 & 75 & 29 & 34 & 49 & 16 & 14 & 10 \\
Dry bucket, 1983-1984 & 52 & 80 & 25 & 20 & 45 & 12 & 16 & 9 \\
Dry to snow, 1982-1983 & 140 & 97 & 23 & 34 & 63 & 18 & 12 & 9 \\
Dry bucket, 1982-1983 & 100 & 70 & 12 & 46 & 57 & 19 & 11 & 4 \\
NADP dry bucket, 1982-1983 & 219 & 174 & 15 & 112 & 102 & 37 & 16 & 3 \\
Dry bucket, 1981-1982 & 72 & 64 & 14 & 50 & 81 & 20 & 20 & 6 \\
NADP dry bucket, 1981-1982 & 204 & 64 & 22 & 78 & 110 & 35 & 20 & 4 \\
NADP dry bucket, 1980-1981 & 123 & 65 & 7 & 43 & 83 & 23 & 19 & 3 \\
NADP dry bucket, 1979-1980 & 95 & 54 & 8 & 30 & 65 & 19 & 23 & 2 \\
Average dry bucket, & $88 \pm 27$ & $67 \pm 9$ & $13 \pm 7$ & $38 \pm 12$ & $66 \pm 16$ & $19 \pm 4$ & $18 \pm 4$ & $5 \pm 3$ \\
1979-1980 to 1983-1984 & & & & & & & & \\
\hline
\end{tabular}

pected for $\mathrm{Cl}^{-}$due to differences in $\mathrm{HCl}$ collection. Dry to snow deposition rates for $\mathrm{SO}_{4}^{-}, \mathrm{NO}_{3}^{-}$and $\mathrm{Cl}^{-}$ were higher than bucket deposition rates for all but the 1983-1984 $\mathrm{NO}_{3}^{-}$data. The average differences between the results obtained using the two methods for the two winters were 28,22 and $54 \%$ for the $\mathrm{SO}_{4-}^{2-}$, $\mathrm{NO}_{3}^{-}$and $\mathrm{Cl}^{-}$dry deposition rates, respectively.

Differences between the two methods for particulate species are harder to predict since they depend on the relative capture efficiencies of an open bucket compared to a snow surface. For the two periods, the average difference in dry deposition rates between the dry to snow and the bucket measurement was 10,14 and $-1 \%$ for $\mathrm{Ca}^{2+}, \mathrm{Mg}^{2+}$ and $\mathrm{Na}^{+}$, respectively. The results for $\mathrm{NH}_{4}^{+}$and $\mathrm{K}^{+}$were mixed. Overall, the agreement between the two methods is better than expected. The reason may be that the standard bucket collector invariably collects small amounts of snow due to the insensitivity of the wet/dry sensor. The presence of snow and frost in the bucket means that most of the time dry deposition is cocurring to a snow or ice surface, rather than to plastic. Thus, the differences between the two collection techniques is minimized.

Average dry deposition bucket results from all 5 years are given at the bottom of Table 3 . The 1982-1983 and 1981-1982 NADP dry bucket data were excluded from the average since a large volume of wet deposition had been collected in both periods. It was assumed that the wet deposition accounted for the observed high dry deposition rates for some species in these samples. Dry to snow data is not included in the average. Comparing the NADP dry deposition data to the dry to snow and dry bucket data suggests that the NADP data would be useful if the excessive collection of wet deposition could be eliminated.

Figure 2 gives a comparison of the individual dry to snow and dry bucket data for $\mathrm{SO}_{4}^{2-}, \mathrm{NO}_{3}^{-}, \mathrm{Ca}^{2+}$, and $\mathrm{Mg}^{2+}$ from both winters. There is a large scatter in the data due to both real differences between the methods and errors introduced into the data by the wet deposition and blank corrections. Even more scatter occurred with some of the other species. As discussed previously (Cadle et al., 1985) wet deposition correc-
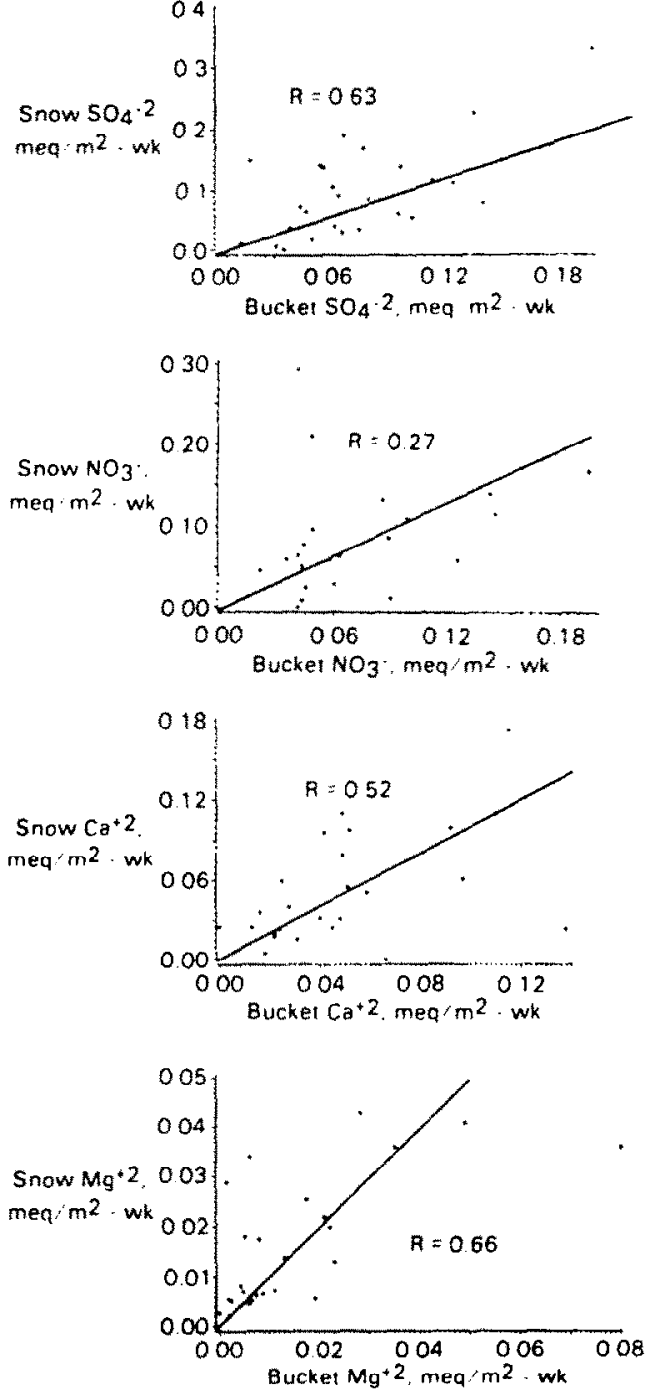

Fig. 2. Comparison of measurements of dry deposition rates to snow and to the conventional dry deposition bucket. Straight line is the equivalence line.

tions to the dry to snow samples averaged from 55 to $100 \%$ (depending on species) for the samples affected and the blanks ranged from 62 to $69 \%$ of the dry deposition values. Thus, these corrections were large. 
Table 4. Dry deposition as a percentage of the total deposition

\begin{tabular}{lccc}
\hline & $1983-1984$ & $1982-1983$ & $1981-1982$ \\
\hline $\mathrm{H}^{+}$ & 1 & 13 & 4.8 \\
$\mathrm{SO}_{4}^{2-}$ & 13 & 30 & 11 \\
$\mathrm{NO}_{3}^{-}$ & 10 & 28 & 12 \\
$\mathrm{Cl}^{-}$ & 24 & 44 & 15 \\
$\mathrm{NH}_{4}^{+}$ & 14 & 25 & 17 \\
$\mathrm{Ca}^{2+}$ & 37 & 45 & 19 \\
$\mathrm{Mg}^{2+}$ & 29 & 47 & 15 \\
$\mathrm{Na}^{+}$ & 31 & 36 & 26 \\
$\mathrm{~K}^{+}$ & 43 & 36 & 21 \\
\hline
\end{tabular}

Dry deposition bucket blanks were very low. However, the wet deposition corrections to the dry buckets were highly variable, and occasionally large. Therefore, the large amount of scatter is not surprising. The best correlation coefficient was 0.66 for the comparison of bucket $\mathrm{Mg}^{2+}$ to snow $\mathrm{Mg}^{2+}$. Thus, while there is good agreement between the average dry deposition values, it is apparent that there can be very large differences in individual values.

Table 4 gives the percentage of the total deposition originating as dry deposition during the three winters. Dry to snow data were used for the 1983-1984 and 1982-1983 winters while dry bucket data were used for the 1981-1982 winter. Dry deposition of $\mathrm{H}^{+}$makes little contribution to the total acidity. Dry deposited $\mathrm{SO}_{4}^{2-}$ and $\mathrm{NO}_{3}^{-}$contributed only $10-13 \%$ of the total deposition of these species during the 1981-1982 and 1983-1984 winters, but were $30 \%$ of the total deposition during the relatively dry 1982-1983 winter. Dry deposition of $\mathrm{Cl}^{-}$was more significant, being $24 \%$ of the total deposited $\mathrm{Cl}^{-}$in $1983-1984$ and $44 \%$ in 1982-1983. Dry deposition of the basic species is also important with as much as $37 \%$ of the $\mathrm{Ca}^{2+}$ being dry deposited even during a heavy snow year.

\subsection{Snowpack}

The cumulative sum of the wet and dry deposition was compared to the snowpack loading of each of the measured species. The comparison served the dual purpose of checking the accuracy of the wet and dry deposition measurements and determining if there were any losses of species from the snowpack in the absence of a thaw. Such losses have been reported by others (Jeffries and Snyder, 1981).

Figure 3 shows the snowpack-total deposition comparison for water, $\mathrm{SO}_{4}^{2-}$, and $\mathrm{NO}_{3}^{-}$for the 1983-1984 winter. 'Wet' water is the water collected by the wet deposition bucket. 'Wet and dry' water includes the water collected in the dry deposition bucket. There is excellent agreement between the snowpack and the 'wet and dry' water up to day 39. The week following day 39 included 4 days with temperatures constantly above freezing. The resulting thaw removed $20 \%$ of the water in the snowpack. This thaw was not accompanied by rain. The agreement between wet and dry $\mathrm{SO}_{4}^{2-}$ and snowpack $\mathrm{SO}_{4}^{2-}$ was also excellent during
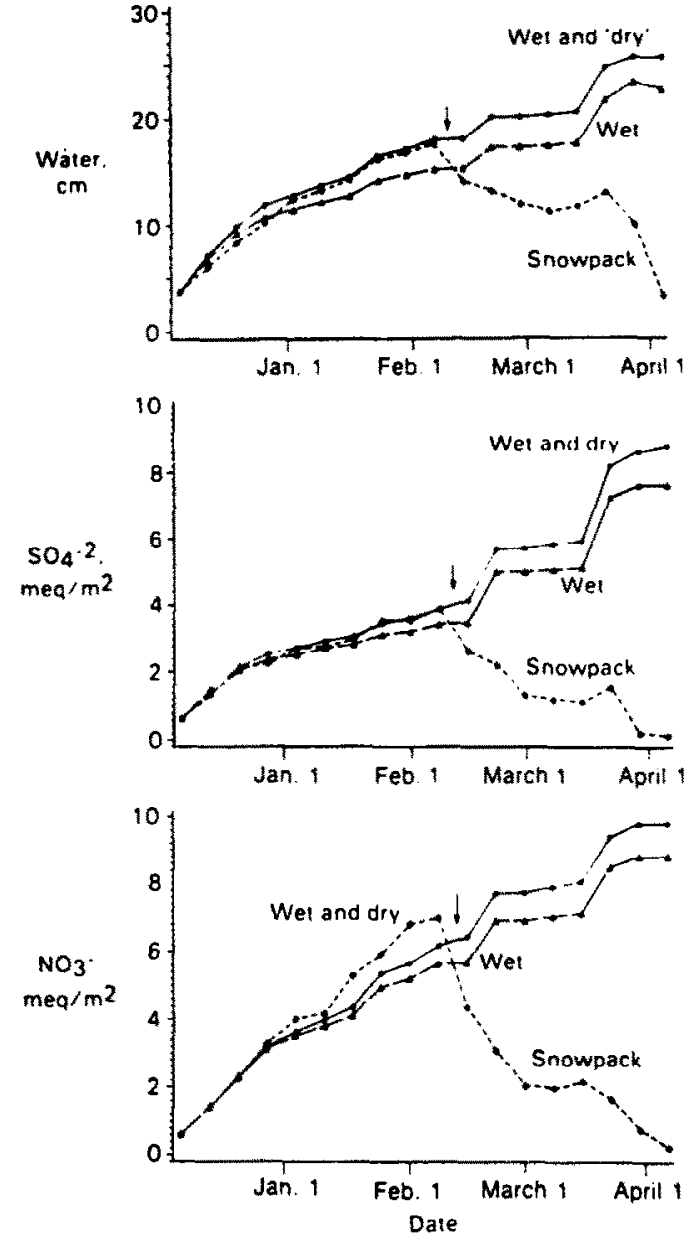

Fig. 3. Comparison of the cumulative wet and dry deposition of water, $\mathrm{SO}_{4}^{2-}$, and $\mathrm{NO}_{3}^{-}$with the snowpack for the 1983-1984 winter. Arrow indicates start of the melt period.

the stable snowpack period, suggesting that the measurements are accurate and no $\mathrm{SO}_{4}^{2-}$ was lost from the snowpack before the thaw period. The $\mathrm{NO}_{3}^{-}$(Fig. 3) and $\mathrm{H}^{+}$(Fig. 4) comparisons show an excess of both species in the snowpack. The cause of these differences has not been identified. However, the fact that most of the $\mathrm{NO}_{3}^{-}$difference occurs at one data point, day 18 , suggests the wet deposition $\mathrm{NO}_{3}^{-}$value may be in error. The cation/anion ratio for this wet deposition sample was very high, 1.54 , in agreement with the possibility that the wet deposition $\mathrm{NO}_{3}^{-}$was too low. Similarly, for $\mathrm{H}^{+}$, much of the difference occurs on day 4. However, the cation/anion ratio for this sample, 1.15 , does not suggest that the $\mathrm{H}^{+}$measurement was too low. Since the plots are cumulative, any wet or dry deposition measurement errors are carried forward through the rest of the study period. Results for $\mathrm{NH}_{4}^{+}$ and $\mathrm{Ca}^{2+}$ are also shown in Fig. 4. Wet and dry deposition exceeds the snowpack loading, but the differences are not large.

Similar comparisons were made for all species for 


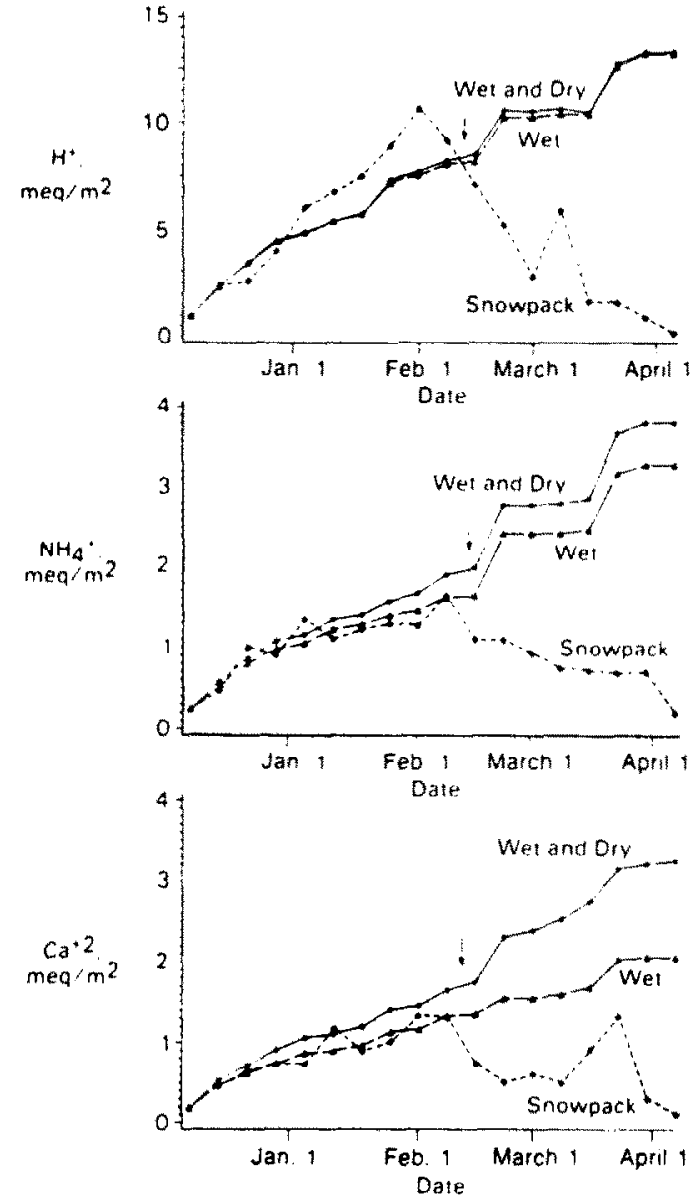

Fig. 4. Comparison of the cumulative wet and $d r y$ deposition of $\mathrm{H}^{+}, \mathrm{NH}_{4}^{+}$, and $\mathrm{Ca}^{2+}$ with the snowpack for the 1983-1984 winter. Arrow indicates start of the melt period.

each study period. The ratio of wet and dry deposition to the snowpack loading for the last week of the stable snowpack period of each winter is given in Table 5. Week-to-week variations in this ratio were at least $\pm 5 \%$. Therefore, small deviations from unity are not significant. The ratios for $\mathrm{H}^{+}, \mathrm{SO}_{4}^{2-}, \mathrm{NO}_{3}^{-}$and $\mathrm{Cl}^{-}$ vary from year-to-year and show no consistent pattern. The averages for the 3 years for $\mathrm{H}^{+}, \mathrm{SO}_{4}^{2-}, \mathrm{NO}_{3}^{-}$and
$\mathrm{Cl}^{-}$are close to unity. Therefore, it does not appear that any significant loss of these species occurs from the snowpack in the absence of a thaw period. $\mathrm{NH}_{4}^{+}$, $\mathrm{Ca}^{2+}$ and $\mathrm{Mg}^{2+}$ were consistently higher in the cumulative deposition compared to the snowpack. Some of the difference is probably due to measurement errors and some could be due to a selective loss of these species from the snow pack. However, we are not aware of any mechanism which could account for such a selective loss. $\mathrm{K}^{+}$is consistently higher in the snowpack than the cumulative deposition. $\mathrm{K}^{+}$is the most abundantly leached cation from litter. Therefore, the high snowpack $\mathrm{K}^{+}$probably reffects contamination by organic material. Hornbeck et al. (1981) found a similar increase in $\mathrm{K}^{+}$in the snowpack.

The comparisons between cumulative wet and dry deposition and the snowpack loading, as well as the comparison between the snow filled buckets and the conventional buckets, indicate that these buckets have dry deposition collection characteristics similar to the natural snow surface for most of the species measured. This result demonstrates that dry deposition collection devices can be used where their surfaces are a close match to the real surface. It also suggests that bulk deposition collection is a good way of measuring total deposition in the winter in snow regions.

\subsection{Throughfall}

All the measurements discussed above were taken in an open field. However, when considering the possible impact of snowmelt, it is necessary to include any throughfall effects on the snowpack chemistry. Throughfall effects for a deciduous and red pine canopy were determined by comparing snowpack compositions under the canopy with the snowpack composition in the open field during the 1982-1983 winter. Composition differences were attributed to throughfall effects, but these differences may also be due to leaching of organic material dropped into the snowpack from the canopy. The snowpack under the red pine canopy had considerably more detritus in it than either the snowpack in the open or the snowpack under the deciduous canopy.

The comparisons for water, $\mathrm{SO}_{4}^{2-}, \mathrm{NO}_{3}^{-}$and $\mathrm{Ca}^{2+}$ are shown in Fig. 5. The water content of the snow pack

Table 5. The ratio of cumulative wet and dry deposition to the snowpack laading for the last week of the stable snowpeck period

\begin{tabular}{lcccc}
\hline Parameters & $1983-1984$ & $1982-1983$ & $1981-1982$ & Average \\
\hline Volume & 1.02 & 1.01 & 0.86 & $0.96 \pm 0.09$ \\
$\mathrm{H}^{+}$ & 0.72 & 1.15 & 1.31 & $1.06 \pm 0.31$ \\
$\mathrm{SO}_{4}^{2-}$ & 1.00 & 1.08 & 1.26 & $1.11 \pm 0.13$ \\
$\mathrm{NO}_{3}^{-}$ & 0.89 & 0.88 & 1.18 & $0.98 \pm 0.17$ \\
$\mathrm{Cl}^{-}$ & 0.86 & 0.98 & 1.24 & $1.03 \pm 0.19$ \\
$\mathrm{NH}_{4}^{+}$ & 1.16 & 1.36 & 1.34 & $1.29 \pm 0.11$ \\
$\mathrm{Ca}^{2+}$ & 1.25 & 1.66 & 1.74 & $1.55 \pm 0.26$ \\
$\mathrm{Mg}^{2+}$ & 1.11 & 1.20 & 2.11 & $1.47 \pm 0.55$ \\
$\mathrm{Na}^{+}$ & 0.82 & 0.65 & 1.19 & $0.89 \pm 0.28$ \\
$\mathrm{~K}^{+}$ & 0.45 & 0.53 & 0.94 & $0.64 \pm 0.26$ \\
\hline
\end{tabular}



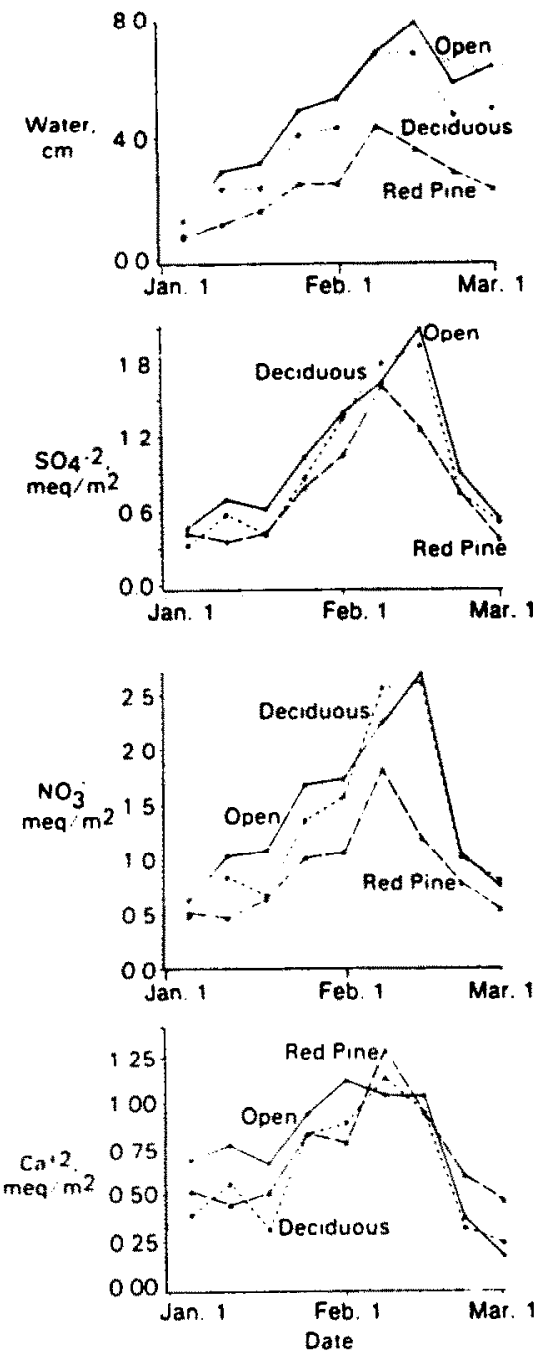

Fig. 5. Comparison of water, $\mathrm{SO}_{4}^{2-}, \mathrm{NO}_{3}^{-}$, and $\mathrm{Ca}^{2}$ in the snowpack in an open area and under a red pine and a deciduous canopy during the 1982-1983 winter.

was highest in the open area and lowest under the red pine canopy. It is assumed that the amount of snow held in the canopy was small compared to the snowpack volume. Since these areas were only $6 \mathrm{~km}$ apart, it is unlikely that the difference in water content is due to differences in wet deposition. The excellent agreement between wet deposition and snowpack water content in the open area showed that sublimation was not significant at that site. However, sublimation of the snow temporarily caught in the canopy may be significant. Because of the water content differences between the sites, the comparisons of various species was made on a deposition quantity basis rather than a concentration basis. Thus, while the $\mathrm{SO}_{4}^{2-}$ and $\mathrm{Ca}^{2+}$ concentrations were much higher under the red pine canopy than in the open, the actual amounts of $\mathrm{SO}_{4}^{2-}$ and $\mathrm{Ca}^{2+}$ at the two locations were very similar. On the other hand, the amount of snowpack $\mathrm{NO}_{3}^{-}$under the red pine canopy was consistently lower than in the
Table 6. Snowpack comparisons between an open field and under deciduous and red pine canopies

\begin{tabular}{lcc}
\hline Parameter & $\begin{array}{c}\text { Ratio } \\
\text { Deciduous/open }\end{array}$ & $\begin{array}{c}\text { Ratio } \\
\text { Red pine/open }\end{array}$ \\
\hline Water & 0.91 & 0.56 \\
$\mathrm{H}^{+}$ & 1.08 & 0.54 \\
$\mathrm{SO}_{4}^{2-}$ & 1.01 & 0.81 \\
$\mathrm{NO}_{3}^{-}$ & 1.05 & 0.60 \\
$\mathrm{Cl}^{-}$ & 1.02 & 3.70 \\
$\mathrm{NH}_{4}^{+}$ & 1.08 & 0.85 \\
$\mathrm{Ca}^{2+}$ & 1.02 & 1.08 \\
$\mathrm{Mg}^{2+}$ & 0.89 & 1.47 \\
$\mathrm{Na}^{+}$ & 0.75 & 4.00 \\
$\mathrm{~K}^{+}$ & 0.92 & 0.88 \\
\hline
\end{tabular}

The ratios are based on the total content of the snowpack. Data is the average ratio for the 2 weeks preceding the first thaw.

open or under the deciduous canopy. Table 6 compares the amounts of each measured species at the three sites. This data is the average of the last 2 weeks before the first thaw period. Considering the week-to-week variations in the ratios, differences of $10 \%$ should not be considered significant. Overall, there was little difference between the open field and the deciduous canopy sites. Therefore, it is concluded that throughfall effects for the deciduous canopy were not signifcant. The biggest differences between the red pine and open areas were for $\mathrm{Na}^{+}$and $\mathrm{Cl}^{-}$. The large increase in $\mathrm{Na}^{+}$and $\mathrm{Cl}^{-}$suggests that roadsalt was deposited on the trees and snow. This site was closer to a lightly traveled road than the other two sites. The lower $\mathrm{K}^{+}$in the red pine snowpack compared to the open area was a surprise since there was considerably more detritus in the red pine snowpack. Therefore, it appears that this material did not have a large effect on the chemical composition of these snow samples. Cation to anion ratios were also compared to see if the organic matter added any undetected anions. The average cation to anion ratios for the snowpack from the open, deciduous, and red pine areas were $1.03 \pm 0.15,1.02 \pm 0.07$ and $1.12 \pm 0.10$, respectively. The differences in the ratios do not appear to be significant. Overall, the snowpack under the red pine canopy had less $\mathrm{NO}_{3}^{-}$ and more $\mathrm{Mg}^{2+}$ than the snowpack in the open area. The effect of these changes is a large decrease in the acidity of the snowpack under the red pine canopy.

\section{SUMMARY}

Wet and dry deposition were monitored at a rural northern Michigan site during three winters. Average dry deposition measured directly to a snow surface is in reasonable agreement with the average dry deposition measurements made with the conventional bucket technique. During an average precipitation winter, the dry deposition to snow inputs of $\mathrm{H}^{+}, \mathrm{SO}_{4}^{2-}, \mathrm{NO}_{3}^{-}$and $\mathrm{NH}_{4}^{+}$are each less than $15 \%$ of the total deposition of each species. The dry deposition to snow of $\mathrm{Ca}^{2+}$, $\mathrm{Mg}^{2+}, \mathrm{Na}^{+}, \mathrm{K}^{+}$and $\mathrm{Cl}^{-}$are a larger percentage of the 
total input. Good agreement was found between the total deposition quantities and the amounts of the various species in the snowpack before the first thaw period. Therefore, it is concluded that significant losses of ionic species did not cocur in the absence of a thaw. Comparison of the snowpack composition in an open field with the composition under a deciduous canopy and a red pine canopy showed negligible deciduous canopy throughfall effects, but a significant decrease in $\mathrm{H}^{+}$and $\mathrm{NO}_{3}^{-}$under the red pine canopy.

Acknowiedgement-The authors are thankful for the metals analyses performed by Kenneth Kennedy and the analyses and data reductions performed by Patricia Mulawa.

\section{REFERENCES}

Barrie L. A., Anlauf K, Wiebe H. A. and Felin P. (1984) Acidic pollutants in air and precipitation at selected rural locations in Canada. In Deposition Both Wet and Dry, Acid Precipitation Series, Vol. 4 (edited by Hicks B.). Ann Arbor Science.

Cadle S. H., Dasch J. M. and Grossnickle N. E. (1984) Northern Michigan snowpack-a study of acid stability and release. Atmospheric Environment 18, 807-816.

Cadle S. H, Dasch J. M. and Mulawa P. A. (1985) Atmospheric concentrations and the deposition velocity to snow of nitric acid, sulfur dioxide, and various particulate species. Atmospheric Environment 19, 1819-1827.

Dasch J. M. (1984) Direct measurement of dry deposition to a polyethylene bucket and various surrogate surfaces. Entir. Sci. Technol: 19, 721-725.

Forland E. J. and Gjessing Y. T. (1975) Snow contamination from washout/rainout and dry deposition. Almospheric Environment 9, 339-352

Galloway J. N. and Likens G. E. (1981) Acid precipitation: the importance of nitric acid. Aimospheric Environment 15, $1081-1085$.

Granat L. and Johansson C. (1983) Dry deposition of $\mathrm{SO}_{2}$ and $\mathrm{NO}_{2}$ in winter. Atmospheric Environment 17, 191-192.

Hicks B. B., Wesely M. L. and Durham J. L. (1980) Critique of methods to measure dry deposition, EPA-600/9-80-050.

Hornbeck J. W., Likens G. E. and Eaton J. S. (1981) Seasonal patterns in acidity of precipitation and their implications for forest stream ecosystems. Wat. Air Soil Pollut. 7, 355-365.

Jefries D. S. and Snyder W. R. (1981) Variations in the chemical composition of the snowpack and associated waters in central Ontario. In Proc. 38th Eastern Snow Conference (edited by Goodwin B. E.), pp. 11-22.

Johannes A. H., Altwicker E. R., Clesceri N. L., lerardi M. E. and Jenness S. (1982) Relationships between wet deposition, dry deposition, and throughfall chemistry. $75 \mathrm{th}$ Annual Air Pollut. Control Ass. Meeting, Paper 82-41.3.

Michigan Department of Agriculture and Michigan Weather Service (1971) Climate of Michigan by Stations.

Reynolds B. (1983) The chemical composition of snow at at rural upland site in mid-Wales. Atmospheric Environment $17,1849-1851$. 